\title{
A Complex Legacy
}

\section{Louis Bouyer and the Metaphysics of the Reformation}

\author{
Silvianne Aspray, Pembroke College, University of Cambridge
}

\begin{abstract}
$\underline{\text { Abstract }}$
Based on a discussion of Louis Bouyer's thesis about the metaphysics of the Reformation in The Spirit and Forms of Protestantism, this essay considers the methodological and hermeneutical issues involved in enquiring into the metaphysical commitments of Reformation theology. A case study of the theology of the Reformer Peter Maryr Vermigli is employed for the argument that Reformation metaphysics was a hybrid of elements pertaining both to a nominalist and a participatory ontology. This argument is then taken further by a reflection on the history of reception of the metaphysical complexity which is at the heart of the Reformation legacy.
\end{abstract}

Total word count: $11^{\prime} 250$ words

In the wake of the 500-year anniversary of the Reformation, many call for a new return ad fontes reformationis, heralding a Protestant ressourcement. Louis Bouyer, writing in 1954, challenged the possibility of any such return. ${ }^{1}$ The "irreducible complexity" of the theological principles of sixteenth-century Protestantism, he contended, would inadvertently backfire on those wishing to retrieve them. Historically, Bouyer argued moreover that each return to a self-avowedly 'orthodox' Protestantism tended to produce a liberal counter reaction, and "if 'orthodox' Protestants regularly beget 'liberal' Protestants, the 'neo-orthodox', whom liberals engender in their turn, only bring forth atheists, who view, no longer with hate but merely with scorn, any religion claiming to be transcendent." ${ }^{2}$ The roots of this development, according to Bouyer, go beyond a merely

\footnotetext{
${ }^{1}$ Louis Bouyer, Du Protestantisme À l'Église (Paris: Éditions du Cerf, 1954); the above and all following references are made to the English translation: Louis Bouyer, The Spirit and Forms of Protestantism, trans. A.V. Littledale (London: Scepter Publishers, 2001), 63; 210.

2 Bouyer, The Spirit and Forms of Protestantism, 210.
} 
sociological rule of action and reaction; rather, they lie in the complexity of Reformation theology itself. This thesis on the beginnings and development of Protestantism has barely been received so far; neither in Catholic theology where Bouyer's nuanced but decidedly critical tone did not dovetail easily with the irenic spirit post-Vatican II, nor in Protestant theology where Bouyer's work tended to be dismissed as nothing more than a personal apology of the author, a one-time Protestant converted to Catholicism. ${ }^{3}$

Two related but separate facets can be distinguished in Bouyer's thesis; his view on the metaphysics of the Reformation, on one hand, and its effect throughout the history of Protestantism, on the other hand. I shall discuss and qualify both facets of Bouyer's argument, in particular through a case study of the theology of the Reformer Peter Martyr Vermigli, before considering the hermeneutical difficulties involved in a return ad fontes reformationis.

With regard to the first aspect of Bouyer's argument, we shall see that he highlights the genuinely scriptural and traditional insights of Reformation theology and wishes to distinguish them from its more polemical, "negative" elements. He concludes that the presence of the latter, right from the outset, was due to the Reformation's unwitting inheritance of a nominalist metaphysics. The complexity of the Reformation, for Bouyer, is thus a complexity comprising the Reformers' positively Christian insights and the unlucky setting of the latter in a "vitiated framework". Based on my own research on the Reformer Peter Martyr Vermigli, I concur with Bouyer that the implied metaphysics of the Reformation was complex, yet I will argue that the character of this complexity is more paradoxical than Bouyer believed. Reformation thought, I venture, was complex not only insofar as it combined positive insights and (what Bouyer thought) a negative metaphysical framework, but insofar as it was engaged in two different, mutually excluding metaphysical frameworks. I will develop this claim through discussing the difficulties of Bouyer's heuristic lens, and through studying the implied metaphysics of Peter Martyr Vermigli's understanding of justification by faith.

\footnotetext{
${ }^{3}$ See for instance Gabriel Widmer, "Du protestantisme à l'Église (Book Review)," Revue de théologie et de philosophie 5, no. 1 (1955): 41-50.
} 
The second facet of Bouyer's thesis concerns the history of this complex Reformation heritage. The story of Protestantism, for him, is one in which a corrupt metaphysical framework gradually overgrew the Christian truths affirmed by the Reformation. Had it not been for a number of revivals, the "positive principles of the Reformation" would long have been stifled. Based on my qualification of the kinds of metaphysical frameworks present in Reformation thought, I propose to modify Bouyer's vision of the history of Protestantism. If it is true that from its very beginnings, Protestantism was engaged in two mutually exclusive metaphysical frameworks, then a crucial question is what effects this complexity had on the development of Protestantism. I will argue that the metaphysical complexity of the Reformation enabled Protestants to engage in and accommodate whatever metaphysical structures became dominant over the centuries. This capacity to accommodate predominant structures, however, in turn meant that it became harder for Protestants to perceive the complexity at the heart of their own foundations in the Reformation. I suggest that it is necessary, therefore, to consider the history of "looking back"; the history of the hermeneutical conditions of the retrievals of the Reformation through the ages.

\section{Louis Bouyer and the "Irreducible Complexity" of the Protestant Reformation}

Louis Bouyer's first aim in The Spirit and Forms of Protestantism is to delineate the "authentic truths of Christianity" as they were brought to light afresh by the Protestant Reformation. ${ }^{4}$ The free gift of salvation, the sovereignty of God, the authority of Scripture - all these were the constitutive "positive principles of the Reformation" as he calls them. By enquiring into the principles of the Reformation, and indeed of Protestantism, Bouyer follows a long tradition of (mainly German) nineteenth-century scholarship which aimed at distilling the principles of Protestantism. What distinguishes Bouyer's approach, however, is his refusal of an antagonistic starting point. Whereas Adolf von Harnack, for instance, asserted that "Protestantism is primarily to be understood in opposition

\footnotetext{
4 Bouyer, The Spirit and Forms of Protestantism, 229.
} 
to Catholicism" in that Protestantism is was both a "critical reduction" of Catholicism in terms of its doctrine of salvation, and its "revolution" in terms of how it views the authority of the church, ${ }^{5}$ Bouyer does not presume that Protestantism is merely the polemical other of Catholicism. Protestantism, he holds, "is not, in the first place, a negation but an affirmation, positive and Christian." 6 His stated aim is to unearth Protestantism's "positive" principles, apart from their polemical opposition to Catholicism. This quest remains relevant, as negative definitions of Protestantism are still prevalent - as seen for instance in the Oxford English Dictionary's definition of Protestantism as "the religion of Protestants, as opposed to Roman Catholicism." ${ }^{7}$

Nonetheless, Bouyer had to account for the fact that in its historical origins, Protestantism was quite antagonistic. Whatever positive principles the Reformers may have held, they were inextricably linked with the polemics against the Roman Catholic church of their day. Bouyer recognises this, yet suggests that "there is no intrinsic connection between what [Protestantism] affirms and what it denies." 8 This thesis - that the positive principles of the Reformation are not necessarily or intrinsically connected to its negations - is central to Bouyer's work, and a major critical contribution. He goes as far as to say that the "principles of Protestantism, in their positive sense ... must be held to be true and necessary in virtue of Catholic tradition itself." 9

By way of example, the Reformers famously affirmed that human salvation depends fully on and is granted through God's abundant grace, sola gratia. This affirmation, however, was eventually associated with a denial of any hu-

\footnotetext{
5 Adolf von Harnack, Das Wesen des Christentums, 2nd ed. (Gütersloh: Gütersloher Verlagshaus, 1985), 157-65 (my own translation). Similarly, Friedrich Schleiermacher's most pointed theses about the nature of Protestantism are constructed in a contrast to Catholicism: "Protestantism makes the relation of the individual to the church dependent on his relation to Christ, whereas Catholicism makes the relation of the individual to Christ dependent on his relation to the church." Friedrich Schleiermacher, Der christliche Glaube nach den Grundsätzen der evangelischen Kirche im Zusammenhange dargestellt (1821/22), vol. 1, Kritische Gesamtausgabe, Schriften und Entwürfe (Berlin: Walter de Gruyter, 1980), 99 (my own translation).

6 Bouyer, The Spirit and Forms of Protestantism, 22.

${ }^{7}$ http:/ / www.oed.com/view/Entry/153197 (retrieved 29 September 2016).

8 Bouyer, The Spirit and Forms of Protestantism, 63.

9 Ibid., 166-67.
} 
man contribution to, or even implication in salvation, to the point of understanding salvation as merely extrinsic to human beings, with God's grace being like a cloak which covers its recipients while leaving them essentially untouched. ${ }^{10}$ Bouyer asserts that there is no necessary connection between the affirmation of the sola gratia and the denial of any implication of human beings in their salvation, for one can arguably hold the former without the latter. To endorse the view that God's salvific action is a pure gratuitous gift, it is not necessary to subscribe to an understanding of grace as merely extrinsic to human beings.

Given, then, that it is possible to distinguish between the affirmations, or positive principles, of the Reformation as reformulations of biblical Christian truths, on the one hand, and the narrowing of the same for the sake of polemical demarcations, on the other hand, and given that the two are not intrinsically linked, where does the impetus for the negations originate? What was present in the Reformation, Bouyer asks, so bound up with its positive principles, that in the eyes of the Catholic church - the Reformation turned heretical, despite its genuinely Christian principles? Bouyer's answer to this question is "nominalism". The Reformation's negations are, he holds, the offspring of an unholy alliance of Reformation thinking with nominalist metaphysics. Unconsciously, the Reformers inherited a nominalist understanding of how God and the world relate, Bouyer argues, and it was this "vitiated framework" which, when used to expound the positive insights of the Reformation, compromised them. ${ }^{11}$ Hence, Bouyer concludes, if anything, the Reformers were not radical enough. They did not sufficiently realise their own captivity to a nominalist metaphysics. ${ }^{12}$

What, however, is the nominalism Bouyer refers to? It is, he says, at core a radical empiricism which reduces all being to what is perceived. This "empties out, with the idea of substance, all possibility of real relations between beings, as well as the stable subsistence of any of them" and "ends by denying to the

\footnotetext{
10 Ibid., 168.

11 Cf. ibid., 231.

12 Cf. ibid., 184.
} 
real any intelligibility, conceiving God himself only as a Protean figure impossible to apprehend."13 Indeed, in such a system, every being is seen as a monad, impenetrable by any other. This is also the case because "being is no more than a word without content"14 - which in turn means that the concept of an ontological difference between God and creation becomes unintelligible. God has to be thought as part of the same ontological order as human beings, distinguished from them mainly through his power. 15 "Under such conditions", Bouyer continues, "it seems quite natural that God may 'declare just' the sinner, leaving him as much a sinner as before ... If he did not do so, nothing would distinguish him from us; his transcendent sovereignty would disappear. Doubtless he would remain greater than us, but within the same order."16 In these circumstances, moreover, whatever God does cannot and must not be done by human persons and vice versa. Human actions can be seen as taking something away from what is rightfully God's in a kind of zero-sum game. ${ }^{17}$

In consequence, Bouyer argues, both the Reformers and their Catholic counterparts were often trapped in false dilemmas: "either a grace that saves us ... without affecting us, or a grace that saves us with our independent collaboration, so that, properly speaking, it is we who have to save ourselves"; 18 "either a God who is all while man and the world are literally nothing, or a man and a world having real powers and value, though limited, and a God who is no more than the first in a series." 19 "The true theological position", transcending these dilemmas, Bouyer contends, would be that human persons are themselves only as they recognize their radical dependence on the Creator; "this does not mean

\footnotetext{
13 Ibid., $184 \mathrm{f}$.

14 Ibid., $185 f$.

15 Cf. ibid., 186.

16 Ibid.

17 For the purpose of the argument, I merely wish to present Bouyer's notion of "nominalism", without passing judgement on whether his portrayal of nominalist philosophy or theology is balanced or fair. It is to be noted that in The Spirit and Forms of Protestantism, Bouyer neither gives evidence for the sources of his notion of nominalism, nor engages with primary texts.

18 More recently, Charles Morerod has argued along similar lines. Cf. Charles Morerod, Ecumenism and Philosophy: Philosophical Questions for a Renewal of Dialogue (Ann Arbor MI: Sapientia Press of Ave Maria University, 2006).

19 Bouyer, The Spirit and Forms of Protestantism, 187.
} 
that creation is a fiction, legal or otherwise, but the most authentic of all realities." 20 That such a position did not seem to have occurred to either side of the debate, Bouyer suggests, is because their thinking was trapped in a nominalist framework.

This is, then, what constitutes for Bouyer, the above-mentioned "irreducible complexity" 21 of Protestantism. Protestantism is, right from the start, a complex conglomerate of positive affirmations retrieving genuine Biblical and traditional truths, on the one hand, and a detrimental nominalist metaphysics, on the other hand. The components of this union were moreover not equally weighed, since the nominalist metaphysics provided the framework in which the positive principles of the Reformation were enunciated, and thus determined a good deal of their scope. That the positive affirmations of the Reformation were entangled with negations and often presupposed ultimately unhelpful dichotomies is thus, for Bouyer, owing to the metaphysical framework in which they were expressed. The tragic element of this, moreover, is that the framework itself was not something that the Reformers consciously chose to embrace: "Brought up on these [viz. nominalist] lines of thought ... the Reformers could only systematize their very valuable insights in a vitiated framework." 22

Taking a few steps back from the specificities of this argument, let us consider its method and the hermeneutical lens employed by Louis Bouyer. This discussion will eventually lead us to a reassessment of the nature of the alleged complexity of the Reformation.

\section{What Complexity? Metaphysical Frameworks in the Reformation}

On a formal level, Bouyer's argument is one for an enhanced awareness of metaphysics in its interdependence with theology. This is to be welcomed, especially in the case of the study of Reformation theology, for it is rare that the Protestant Reformation is considered from a metaphysically aware point of

20 Ibid., 189.

21 Ibid., 63.

22 Ibid., 231. 
view: philosophical theologians interested in genealogical accounts of the development of Western metaphysics often leave out the Reformation from among the subjects of their investigation, ${ }^{23}$ while Reformation scholars, on the other hand, do not frequently engage in metaphysical questions. ${ }^{24}$

To be sure, there is a considerable body of scholarly literature on the influence of Medieval and late Medieval philosophical thought, especially the via antiqua and the via moderna, on the Reformers. This literature, however, mostly settles for enquiring into direct influences of certain Medieval authors on Luther, Calvin and others, often taking explicit references in the work of the latter as their starting point. ${ }^{25}$ Such a method is certainly valuable, even though the use of "influence" as a category is not without its problems. For, to say that the Reformation is influenced by this or that strand of Medieval thought means to start from the perspective of the Reformation from the outset, potentially reducing the influencers to their later-day reception. Moreover, there is the danger of tacitly assuming a simplistic model of causality in history; as if every development in history could be traced to and fully explained by a finite number of influences. Heiko Oberman - one of the most notable researchers on the relationship between the Reformation and the Late Middle ages, and, incidentally, a sharp critic of Louis Bouyer ${ }^{26}$ - understood this danger well, and established that when employing the category of "influence", one ought not to enquire into

\footnotetext{
${ }^{23}$ See for instance John Milbank, Theology and Social Theory: Beyond Secular Reason (Oxford: Blackwell Publishers, 1990); Adrian Pabst, Metaphysics: The Creation of Hierarchy (Grand Rapids, MI: Eerdmans Publishing, 2012).

24 There are exceptions, such as Richard A. Muller, "Not Scotist: Understandings of Being, Univocity, and Analogy in Early Modern Reformed Thought," Reformation and Renaissance Review 14, no. 2 (2012): 127-50. Muller, however, limits his enquiry into metaphysical treatises of the sixteenth and seventeenth century to whether or not they explicitly (dis)agree with Scotus on the univocity of being.

${ }^{25}$ To mention only a few recent examples: Theodor Dieter, "Luther as a Late Medieval Theologian: His Positive and Negative Use of Nominalism and Realism," in The Oxford Handbook of Martin Luther's Theology, ed. Robert Kolb, Irene Dingel, and Lubomir Batka (Oxford: Oxford University Press, 2014), 31-48; Mark C Mattes, "Luther's Use of Philosophy," Lutherjahrbuch 80 (2013): 110-41; B J Van der Walt, "Philosophical and Theological Influences in John Calvin's Thought: Reviewing Some Research Results," In Die Skriflig 44, no. 3 (2010): 105-27.

${ }^{26}$ Heiko A. Oberman, The Harvest of Medieval Theology: Gabriel Biel and Late Medieval Nominalism (Cambridge MA: Harvard University Press, 1963) see particularly the Postscript on "The Catholicity of Nominalism", p. 423-8.
} 
"the nature of the cause but the structure of the change." 27 However, even Oberman is liable to limit his enquiry to notions and frameworks explicitly employed or referred to by the Reformers. An example from another field of study might help to illuminate this: The art historian Hans Belting, when tracing the influences between the use of perspective in the East and the West, holds that changing between different historical or geographical viewpoints (Blickwechsel) helps to illuminate a certain phenomenon more thoroughly than it could have been from a single perspective. ${ }^{28}$ In our present context, mutatis mutandis, this would mean that a Medieval perspective on the metaphysics of the Reformation - beyond what the Reformers either positively or negatively referred to - would help to bring to the fore certain constellations in Reformation thought which otherwise might not be seen.

This is precisely what seems to be the appeal of Bouyer's method: To read Reformation thought against the negative foil of the metaphysics of nominalism is to introduce a hermeneutic lens external to the Reformation, which makes visible, for instance, that there were reflections of this foil in Reformation thought, but equally, that not everything in the Reformation can be understood through its logic. The external lens reveals what an influence-oriented approach, however methodologically refined, could not have exposed.

Even so, one might object to such an approach that it forcefully imposes categories on the Reformation which are foreign or extraneous to its discourse. Rarely did the Reformers overtly engage in metaphysical questions, after all. Indeed, it is well known that Luther, for instance, overtly disapproved of anything that smacked of scholasticism, with what he would call "metaphysical speculation" certainly falling under this verdict. ${ }^{29}$ In reply to such an objection, however, I would argue that metaphysics cannot, by definition, be an entirely extraneous endeavour to theological reasoning. All reasoning - and especially

\footnotetext{
${ }^{27}$ Heiko A. Oberman, Forerunners of the Reformation: The Shape of Late Medieval Thought (London: Lutterworth Press, 1967), 39.

${ }^{28}$ Hans Belting, Florenz und Bagdad: eine westöstliche Geschichte des Blicks (München: Beck, 2008). ${ }^{29}$ Most famously perhaps, Luther, in his 1517 Disputation against Scholastic Theology, goes as far as to argue that no syllogistic form is valid in theology (WA 1.222-228).
} 
theological reasoning - involves fundamental assumptions on the nature of being, knowledge and language, and ultimately about how the transcendent relates (or does not relate) to the immanent. ${ }^{30}$ These assumptions, however, are metaphysical in nature. So even if some or all of the Reformers were averse to metaphysics, or did not explicitly engage in metaphysical arguments, this does not necessarily mean that they were altogether able to avoid their work having metaphysical implications or involvements. Indeed, their work has a metaphysical dimension insofar as it builds on and conveys a vision of how God and the world relate. There is, therefore, an implied metaphysics at work in the thought of the Reformers, as indeed in any other thought. If this is granted, then it cannot be an entirely alien imposition on their work to examine its metaphysical commitments.

This consideration, however, nuances what we have said above about the appeal of Bouyer's approach. It seems that its main import is to consider the metaphysical commitments of Reformation theology, especially by going beyond approaches which limit metaphysics to whatever is directly referred to by the Reformers as such, or can be traced backwards by way of direct historical "influences". This more general attention to broader metaphysical frameworks lends itself, as we have seen, to gaining a deeper understanding of the internal logic and complexity of the Reformation, and it is for this that Bouyer is to be especially credited. The weakness of his method, however, is his choice of nominalism as his specific hermeneutic lens. Nominalism is a less-than ideal lens through which to assess the Reformation, for at least two reasons.

First, nominalism is a notoriously under-defined term, both generally, and in Bouyer's work itself. According to Bouyer's primary definition of nominalism, as described above, it is characterised by a radical empiricism, coupled

\footnotetext{
30 This has been argued at greater length than it is possible here by scholars wishing to critique the implied metaphysics of modernity. See for instance Hans Boersma, Heavenly Participation: The Weaving of a Sacramental Tapestry (Grand Rapids MI: Eerdmans Publishing, 2011), esp. 19-21; Paul Tyson, Returning to Reality: Christian Platonism for Our Times (Eugene OR: Wipf \& Stock, 2014), esp. 1-8.
} 
with a metaphysics of singulars. However, he also seems to use nominalism interchangeably with William of Ockham's thought. ${ }^{31}$ Historians of the period disagree over whether this equation is appropriate, given both the convergences and divergences between Ockham and other thinkers of the time, such as Gabriel Biel and Pierre d'Ailly, and given also that none of Ockham's contemporaries would have called him a nominalist. ${ }^{32}$ It is moreover contested whether and how nominalism as a concept reaches beyond epistemology into ontology. ${ }^{33}$ Bouyer clearly assumes the latter, taking it for granted that the univocity of being is a characteristic of nominalism. ${ }^{34}$ All of this suggests that - in contrast to Bouyer's seemingly self-evident use of the concept - defining or understanding nominalism is far from evident. ${ }^{35}$ It can be neither useful nor desirable, however, if one's hermeneutic lens cannot be delineated properly.

Second, and somewhat independently of how one decides to understand nominalism, it is not clear how it is to be assessed - both regarding its place in the history of theology and modernity. As we have seen above, Bouyer assesses "nominalism" in unambiguously negative terms. It is, for him, the root of highly problematic, indeed heretical, developments in theology; and he was not alone with this appraisal. Among the Nouvelle Théologie thinkers of Bouyer's time, it was common to deplore the decay of the realist synthesis of reason and faith in the Late Middle Ages, with Étienne Gilson leading the way. ${ }^{36}$ Others, by contrast, wished to defend the "catholicity" of nominalism. ${ }^{37}$ To make matters more

\footnotetext{
31 Bouyer, The Spirit and Forms of Protestantism, 184.

32 William J. Courtenay, "Nominalism and Late Medieval Religion," in The Pursuit of Holiness in Late Medieval and Renaissance Religion, ed. Charles Trinkaus and Heiko A. Oberman (Leiden: Brill, 1974), 26-59.

33 Fritz Hoffmann, “Nominalismus," Historisches Wörterbuch der Philosophie, VI (Darmstadt: Wissenschaftliche Buchgesellschaft, 1984), 874-88.

34 Bouyer, The Spirit and Forms of Protestantism, 185-86.

35 This is moreover highlighted by the fact that scholars have only recently substantially revisited some core concepts associated with it, like God's potentia absoluta and ordinata. William J. Courtenay, "The Dialectic of Divine Omnipotence in the Age of Chaucer: A Reconsideration," in Nominalism and Literary Discourse : New Perspectives, ed. Hugo Keiper, Christoph Bode, and Richard J. Utz (Amsterdam: Rodopi, 1997), 111-21.

36 Étienne Gilson, History of Christian Philosophy in the Middle Ages (London: Sheed and Ward, 1955), 487-520.

37 Oberman, The Harvest of Medieval Theology: Gabriel Biel and Late Medieval Nominalism; Heiko A. Oberman, "The Shape of Late Medieval Thought: The Birthpangs of the Modern Era," in The Pursuit of Holiness in Late Medieval and Renaissance Religion, ed. Charles Trinkaus and Heiko A. Oberman (Leiden: Brill, 1974), 3-25.
} 
complicated still, scholars of the history of ideas have moreover repeatedly associated "nominalism" with the genesis of modernity ${ }^{38}$ - thereby further refracting and entangling anyone's assessment of it by means of their respective stance on modernity. This again underlines quite how fraught is Bouyer's hermeneutical lens through which to assess the metaphysics of the Reformation.

We have seen so far that Bouyer's methodology has the appeal and advantages of attending to the general metaphysical framework (or frameworks) of the Reformation. Its difficulties, however, lie with the specific kind of framework he considers as his tool or "lens", as I have called it. This leads to the questions whether there are alternatives to Bouyer's hermeneutic lens which retain the benefits of a metaphysical vision while sidestepping the problems associated with "nominalism".

The alternative I wish to propose takes its cue from the debates around the beginnings of modernity just mentioned. French historians of the Middle Ages have recently contributed to these debates by dating the shifts in modal logic and metaphysics which eventually paved the way for modernity further back than Ockham or "nominalism". André de Muralt, Jean-François Courtine, Olivier Boulnois and others have argued that Ockham is to be seen as part of a tradition which originated earlier, merely making more explicit certain metaphysical configurations which appeared for the first time in the thirteenth century, most prominently in the work of John Duns Scotus. ${ }^{39}$ These configurations, so the argument goes, will eventually determine not only "nominalism", but

\footnotetext{
38 See the accounts of scholars as different as, for example: Louis K. Dupré, Passage to Modernity: An Essay in the Hermeneutics of Nature and Culture (New Haven: Yale University Press, 1993); Michael A. Gillespie, The Theological Origins of Modernity (Chicago: University of Chicago Press, 2008); Thomas Pfau, Minding the Modern: Human Agency, Intellectual Traditions, and Responsible Knowledge (Notre Dame IN: University of Notre Dame Press, 2013).

39 Olivier Boulnois, Être et représentation: Une généalogie de la métaphysique moderne à l'époque de Duns Scot, XIIIe-XIVe siècle (Paris: Presses Universitaires de France, 1999); Olivier Boulnois, Métaphysiques rebelles: genèse et structures d'une science au Moyen Âge (Paris: Presses universitaires de France, 2013); André de Muralt, Néoplatonisme et Aristotélisme Dans La Métaphysique Médiévale: Analogie, Causalité, Participation (Paris: Vrin, 1995); Jean-François Courtine, Inventio Analogiae: Métaphysique et Ontothéologie (Paris: Vrin, 2005); this French tradition has moreover been introduced to the anglophone academia chiefly through the work of John Milbank and Catherine Pickstock (for example John Milbank, Beyond Secular Order: The Representation of Being and the Representation of the People [Chichester: Wiley-Blackwell, 2013]; Catherine Pickstock, After Writing: On the Liturgical Consummation of Philosophy [Malden MA: Blackwell Publishers, 1998]; Catherine Pickstock, "Duns Scotus: His Historical and Contemporary Significance," Modern Theology 21, no. 4 [2005]: 543-74).
} 
also modernity. ${ }^{40}$ What, however, are they? In brief, two of the most crucial innovations were a univocal understanding of being, and an ensuing new notion of causality. ${ }^{41}$ These two, I propose, constitute a more clearly defined, and hence more useful, hermeneutic lens through which to read Reformation thought.

Applying this lens means to pose the following question to any author or body of thought: Is "being" thought to be a neutral category, applying to both God's as well as created being, or is there a pre-eminent Divine Being in which all other being participates? In the case of the latter, created being is fundamentally and ontologically dependent on God's being, and there are no pockets of reality where created beings stand or act autonomously. The relation between Divine and human causation, in this context, can only be thought of in terms of influentia. When St. Bernhard, for instance, spoke of human and Divine collaboration or cooperation, he took it for granted that human action was "underwritten" by its participation in the Divine. By contrast, when "being" is seen as neutral and univocal, and human beings no longer participate in the Divine qua being, their causal relationship to the latter changes. God and human beings, when possessing being univocally, can share in an action in such a manner as to divide its portions. God's share in an action performed by a human person can be to concur to it, hence the new concept of framing Divine and human causality in terms of concursus. Or, alternatively, if God's and the human person's intentions do not coincide, their respective actions can interfere or compete with each other.

So far, I have argued why it makes sense, when focussing on the metaphysics of Reformation thought, to attend to structures which are both more abstract and more precise than "nominalism" and employ them as the negative foil against which to read the complexities of the Reformation.

\footnotetext{
40 This link between John Duns Scotus and modernity has been criticized for various reasons. For a good overview of the criticisms by Richard Cross and Thomas Williams, see Daniel P. Horan, Postmodernity and Univocity: A Critical Account of Radical Orthodoxy and John Duns Scotus (Minneapolis: Fortress Press, 2014), esp. chapter 3.

${ }^{41}$ In using these concepts as tools, I am not passing judgement on the above-mentioned genealogical accounts or the way in which these concepts feature in them. Neither is it possible, in the present context, to engage in discussions about how the univocity of being, for instance, is understood in primary texts of the late middle ages or early modernity.
} 
In a next step, in order to substantiate and exemplify the use of such a method, I wish to present a brief case study. We shall see that this new hermeneutic lens will reveal another, and far deeper complexity within Reformation thought than Bouyer was able to perceive with the lens he employed. Granted that our case is representative of the Reformation, then the Reformation was not just complex in that some of its genuinely Christian principles were thwarted by a negative metaphysical framework. Rather, it seems that there is not one single metaphysical framework in place in Reformation thought, but two, arguably mutually exclusive, metaphysical frameworks.

\section{A Case Study: Peter Martyr Vermigli on Justification and Faith}

The case study I would like to present here springs from my research on Peter Martyr Vermigli. The Italian-born Reformer taught as a professor in Strasbourg, Oxford and Zurich,42 was prized highly by Bucer, Calvin, Cranmer and Bullinger, and arguably was a more important figure historically than it is often recognized today. ${ }^{43}$ What makes him particularly interesting with regard to enquiring into Reformation metaphysics is his Italian background, and especially his education at the university of Padua, which was a hub of Aristotelian learning at the time. ${ }^{44}$ While the results of a case study on Vermigli cannot claim to be representative for the Reformation as a whole, what they can provide nonetheless, is an indication of the metaphysical commitments of a Reformer who was far from a lone wolf, being supremely well-connected with and esteemed by other Reformers both on the continent and in England.

\footnotetext{
42 The best accounts on Vermigli's bio- and bibliography, apart from the eulogy written by his contemporary Josiah Simler (in: Peter Martyr Vermigli, Life, Letters, and Sermons, trans. John Patrick Donnelly, vol. 5, The Peter Martyr Library (Kirksville MO: Sixteenth Century Journal Publishers, 1999, 9-62) are Philip M. McNair, Peter Martyr in Italy: Anatomy of Apostasy (Oxford: Oxford University Press, 1967); Marvin W. Anderson, Peter Martyr, A Reformer in Exile (15421562): A Chronology of Biblical Writings in England and Europe (Nieuwkoop: De Graaf, 1975). 43 John Patrick Donnelly, Calvinism and Scholasticism in Vermigli's Doctrine of Man and Grace (Leiden: Brill, 1976), see especially chapter seven on “The Influence of Martyr's Thought”.

44 On the importance of Aristotelianism in Italian universities of the time see Paul Oskar Kristeller, "Renaissance Aristotelianism," Greek, Roman and Byzantine Studies 6, no. 2 (Summer 1965): 157-174. More specifically on the Paduan school see John H. Randall, "Paduan Aristotelianism Reconsidered," in Philosophy and Humanism: Renaissance Essays in Honor of Paul Oskar Kristeller, ed. Paul Oskar Kristeller and Edward P. Mahoney (Columbia University Press, 1976).
} 
The source I will focus on for this study is the locus on justification which forms part of Vermigli's Romans commentary. This commentary was published in 1558, and dates from the time when Vermigli lectured on the letter to the Romans as Regius professor of theology in Oxford in 1550. After having lectured on the first eleven chapters of the letter to the Romans, Vermigli chooses to "treat more fully the topic of justification", 45 elaborating on the question "whether men are justified by works or by faith". In what follows, we shall concentrate first on his understanding of justification and, second, on faith.

For God, to justify can mean either of two things, Vermigli explains; it refers to the act of causing someone to be just either in re or in existimatione (in fact or in judgement). When God justifies in re, He endows human beings with his Spirit and renews them fully, giving them a righteousness (iustitia) which inheres and adheres to their souls by His goodness through Christ. Moreover, when He has renewed human beings in this way, He also grants them right and holy works. By their frequent use, there is born in them a habit by which they are "inclined to right and holy living". ${ }^{46}$ The alternative meaning of "to justify", namely for God to do so in existimatione, is that He counts human beings just (pro iusto habere) through His judgement or assertion. Since, however, there are these two significations of being justified, either in re or in existimatione,

"and since the same God is author of both, which of the two should we follow in the proposed discussion? The latter, precisely because the renewal infused by the Spirit of God and our righteousness, insofar as [it is] a habit acquired from good works, are imperfect and lacking as long as we live here, so that if it was to be arbitrated, we would not at all be able to stand before the divine judgement seat by virtue of them." 47

\footnotetext{
45 This and all following English translations, unless otherwise indicated, are taken from Pietro Martire Vermigli, Predestination and Justification: Two Theological Loci, ed. Frank A. James (Kirksville MO: Truman State University Press, 2003), here 87. All Latin quotations are taken from the 1558 version of the Romans Commentary: Pietro Martire Vermigli, In Epistolam S. Pauli Ad Romanos ... Commentarii Doctissimi (Basel: P. Perna, 1558).

${ }^{46}$ Vermigli, Predestination and Justification, 87. Latin: “... opera largitur recta et sancta, quorum usu atque frequentia paritur in animo nostro qualitas, vel ... habitum, quo propensi efficimur ad probe sancteque vivendum." (Vermigli, Ad Romanos, 517.)

47 "Cumque sint duo haec significata iustificandi, scilicet, aut re, aut existimatione, ac utriusque Deus idem sit author, utrum ex duobus in disputatione proposita sequemur? Posterius, idque propterea quod renovatio Dei spiritu afflata, et iustitia nostra quoad habitum ex bonis operibus acquisitum, adeo sunt dum hic vivimus imperfecta et manca ut per ea, si disceptandum sit, at tribunal divinum minime possimus persistere." (Vermigli, Ad Romanos, 517.)
} 
What Vermigli does here, is first to limit the scope of the treatment which follows to justification in existimatione. Does this mean, however, that he rejects the possibility of justification in re altogether? This can hardly be the case, for, even though he gives priority to forensic justification "in the proposed discussion", he clearly affirms that God is the author of both a forensic and a real (infused and formative) justification. Vermigli holds that God does his justificatory work in both ways: through counting human beings just, but also through making them just in reality. The difference between the two concerns neither their origin nor their factuality, it seems, but their "value" in God's judgement. Moreover, it can be seen from the way Vermigli introduces the two modes of justification that there is, for him, a place for both of them, for writes that God sometimes justifies in one way, and sometimes in the other (interdum ... interdum). ${ }^{48}$

Clearly, however, these two manners of justifying do not fully overlap. How then do they relate to each other? It would seem that the real but partial justification needs to be supplemented in the elect by an imputed righteousness, in order for them to avoid condemnation. This is puzzling, for it implies that when God gives his gifts of renewal to human beings, they are not enough to satisfy his own standards. But how could it be that God does not recognise the reality of his own gifts in human beings, in such a way that his judgement is taken in abstraction from them? This paradox, I venture, points to an underlying tension in Vermigli's account, where two metaphysical notions of how God and the world relate grind against each other.

On the one hand, in his theology of justification there are clear indications of a participatory notion of being, that is of a metaphysics where everything that is ours, is ours only by participation in what is God's, and thence receives its finite dignity. Such a structure is at work in Vermigli's description of justification in re, where God is the proper subject of the renewal of the soul and of holy habits: "he endows them with his own Spirit and renews them fully by restoring the strength of their souls ...[and] when he has fashioned and renewed them in

48 Ibid. 
this way he gives right and holy works" ${ }^{49}$ It is not as if renewed souls or holy acts could ever be exclusively or autonomously human - even though they are human souls, and human works. There is no duality here between what God does and what human beings do, and neither is there an understanding of concurrence, in such a way as that each party contributes their share: God gives holy human works, he does not just concur to them. Only a metaphysics which conceives of different intensities of being can envisage such an influentia causality where the higher cause gives both the lower cause and its effect, so that even the human cooperation in the act is not exclusively human. 50

On the other hand, however, the importance that Vermigli places on God's judgement in his justifying act in existimatione suggests that there is another metaphysical framework implied here as well. If God justifies by "ascribing and imputing righteousness",51 then His relationship to humans is not determined by his gift of being which establishes an ontological dependence. Rather than there being a most fundamental, ontological connection between God's being and that of human persons, the relationship between the two is centred around the view or opinion that God has of human beings. This means that human beings could theoretically have their existence independently from God's being. The possibility for such an independence - and be it only theoretical - is indicative of a metaphysics which is not based on a difference in the 'intensity' of being between God and human beings. If human beings can be in abstraction from their dependence on the Creator, then to be is conceived as univocal.

Moreover, we have seen earlier how the univocity of being is related to a certain understanding of action, both human and Divine. The implication of this can be seen here with regard to God's justifying action. Indeed, God's justifying act, insofar as it is forensic, is not ultimately connected with its beneficiary, the justified person. The Divine decision to count human beings just does not touch

\footnotetext{
49 Vermigli, Predestination and Justification, 87, emphases mine. Lat: “...cum suo spiritu illos refingit totusque renovat, instaurando vires animi eorum... Deinde cum iam ipsos sic restituit ac refinxit, opera largitur recta et sancta" Vermigli, Ad Romanos, 517.

50 Cf. Milbank, Beyond Secular Order, 42-49.

51 Vermigli, Predestination and Justification, 87; Vermigli, Ad Romanos, 517.
} 
their existence; it remains extrinsic to them. This means that forensic justification has to have an element of arbitrariness because the Divine act is connected to the being of a particular person in a less-than-necessary way. The reason for this arbitrary element in the connection between the forensic act of justifying and the justified person is, in turn, that the relationship between God and the person is not based on an ontological dependence.

This brief study of Vermigli's theology of justification shows, therefore, that one of his two understandings of justification presupposes a qualitative difference between God's being and the being of his creatures, whereas the other operates in a framework which presumes a univocity of being. These two ways in which to envision the relationship between God and human beings, however, would seem to be mutually exclusive. That Vermigli's theology has one foot in either of them, so to speak, makes it very complex, even at a metaphysical level.

A similar complexity can be found in Vermigli's understanding of faith, which shall constitute our second example. In the locus we have examined so far, right after defining justification, Vermigli proceeds to clarify the term "faith". Vermigli's definition of faith is as follows: Faith is a "firm and assured assent of the mind to the words of God, an assent inspired by the Holy Spirit to the salvation of believers." 52 As he often does with definitions, Vermigli expounds this definition according to the four Aristotelian causes. The material cause of faith, he says, is the word of God, its formal cause is our assent, its efficient cause God's inspiration through the Spirit, and its final cause the salvation of believers.

What is most remarkable about this four-fold distinction is that Vermigli holds one of the four causes of faith - the formal cause - to be exclusively human. This introduces the possibility of there being an element of faith which is purely human, even if only theoretically so, because presumably all four causes are always present at the same time. What this purports in terms of its implied metaphysical structure is a framework which allows for the possibility of pockets of being which have their autonomous ontological standing, independently

52 Vermigli, Predestination and Justification, 90. 
of a participation in God's higher Being - something which is only conceivable when being itself is univocal.

That some aspects of faith could be thought of having their own ontological standing, at least in a theoretical way, seemed to worry Vermigli. For does this theoretical possibility not risk being at the brink of slipping into a kind of semi-pelagianism? If elements of faith can stand independently of God, would this not make them into a kind of work? As if to reply to such questions, Vermigli adds: "If faith itself is considered our work, we cannot be justified by it, since as a work it is imperfect and flawed, far beneath what the law requires. But we are said to be justified by it [faith] because through it we take hold (apprehendimus) of the promises of God and the righteousness and merits of Christ and apply them to ourselves." 53 Vermigli rejects the idea that faith can be any kind of work. What else, then, is the modus operandi of faith? Vermigli says that it works through a human apprehension of what is God's. Granted, the subject of this action remains the human person: we take hold of God's promises and we apply them to us. Nonetheless, if this activity of the believer is not to be her work, then this apprehension has to be fundamentally mediated or given by God.

If this is the case, however, Vermigli is thereby qualifying his own previous definition of faith. Human assent, previously so crucial as its formal cause, is de-emphasized: Faith cannot be an autonomously human "work", or else it is not faith. Our faith, insofar as it is seen as exclusively ours, is imperfect. We cling to what is God's, and this is what grants stability to what is ours, even in the case of our faith. Such a notion of faith, as fully dependent on God, however, is based on an understanding of a radical, ontological dependence of everything which is "ours" on God as its source. This, moreover, is only conceivable in a metaphysics where human beings are ontologically dependent on God.

As with Vermigli's notion of justification, therefore, his understanding of faith seems sometimes to inhabit a metaphysics predicated on the univocity of

53 Ibid., 96; Vermigli, Ad Romanos, 521. 
being, while at other times a metaphysis defined by ontological difference and dependence.

Hence, this case study has shown that attending to the metaphysical structures underlying and sustaining Vermigli's thought brings to the fore a complexity which is more fundamental than the one which Bouyer's hermeneutic lens would have allowed him to perceive, had he studied Vermigli. Vermigli's work, when examined in terms of its structures of being and causality, simultaneously inhabits two different metaphysical frameworks, one based on ontological participation and cooperation, the other on the univocity of being and competition. The fact that Vermigli develops his theology in both of these frameworks makes his work complex - metaphysically complex.

Moreover, based on the history of interpretation of the theology of the two most-researched Reformers, Luther and Calvin, I wish to make the case that our findings about the metaphysical complexity of Vermigli's work can be legitimately said to be representative of the Reformation more broadly. Recent developments in Luther and Calvin scholarship suggest that there are certain "layers" in their oeuvre which previously had been overlooked. Moreover, in contrast to the layers seen previously, these layers are premised - more or less explicitly - on a metaphysical framework in which seems to affirm a qualitative difference of between God's being and the being of human persons.

In the case of Luther, the new development I am referring to is the socalled Finnish school. In contrast to classical Luther scholarship, this school has argued that the heart of Luther's theology of human salvation is not his understanding of justification as imputed to human beings through Christ in faith, or the simul iustus et peccator, but an understanding of human deification, or theosis. ${ }^{54}$ Moreover, as the Finnish school explicitly acknowledges, these newly unearthed aspects of Luther's understanding of salvation are premised on a

\footnotetext{
54 See, for a good overview of the Finnish school: Tuomo Mannermaa, "Theosis als Thema der finnischen Lutherforschung," in Luther und Theosis: Vergöttlichung als Thema der abendländischen Theologie, ed. Simo Peura and Antti Raunio (Erlangen: Luther-Akademie Ratzeburg, 1990); Carl E. Braaten and Robert W. Jenson, eds., Union with Christ (Grand Rapids MI: Eerdmans Publishing, 1998).
} 
metaphysical framework of analogical participation ${ }^{55}$ - in contrast to what tends to be the case with traditional understandings of the workings of justification in Luther.

As for Calvin, Todd Billings has rekindled an older but marginal reading of the Reformer which sees his work as premised on creaturely participation in the Divine. ${ }^{56}$ Such an interpretation paints a rather different picture of Calvin than does more traditional Calvin scholarship, focusing on Calvin's theology of God's glory and the sinfulness of man. While Billings agrees with traditional scholarship that Calvin's theology of human salvation has "irreducibly forensic elements", he nonetheless argues for a "theological logic of participation" at work in Calvin. ${ }^{57}$ As we have seen above, however, a forensic understanding of justification is premised on an understanding of "being" as univocal - quite in contrast to a logic of participation.

If these newer readings of Luther and Calvin are legitimate, then they support our thesis of there is a metaphysical complexity in the Reformation more broadly. For, as Billings explicitly concedes, older interpretations of the Reformers cannot simply be wrong or outdated in the light of newer discoveries. Billings understands himself as exploring and bringing to the fore under-recognised features in the work of Calvin, rather than annihilating old ones, and the same is true for the Finnish school in the case of Luther. If there can be both interpretations of these two main Reformers, the older one predicated on a univocal metaphysics and the newer one premised on a metaphysics of participation, then this suggests that Vermigli was no exception, and that the Reformation legacy is fundamentally, and indeed metaphysically, complex. ${ }^{58}$

\footnotetext{
${ }^{55}$ Sammeli Juntunen argues that "Luther ... does not deny the analogy of being and goodness between God and the world." See Sammeli Juntunen, "Luther and Metaphysics: What Is the Structure of Being According to Luther?," in Union with Christ: The New Finnish Interpretation of Luther, ed. Carl E. Braaten and Robert W. Jenson (Grand Rapids MI: Eerdmans Publishing, 1998), 132.

$56 \mathrm{~J}$. Todd Billings, Calvin, Participation, and the Gift: The Activity of Believers in Union With Christ (Oxford: Oxford University Press, 2007). An earlier example of this kind of reading of Calvin can be seen in the so-called Mercersburg theology, and John Williamson Nevin in particular. See John Williamson Nevin, The Mystical Presence (Hamden, Conn.: Archon Books, 1963).

${ }^{57}$ Billings, Calvin, Participation, and the Gift: The Activity of Believers in Union With Christ, 191.

58 In his concluding remarks, Billings explicitly considers the possibility of there being a metaphysical ambiguity at work in Calvin's theology of participation. Ibid., 194-95.
} 
We will consider some of the implications of such a view of the Reformation for understanding the history and development of Protestantism below. As we shall do so in conversation with the more historical aspect of Bouyer's thesis on Protestantism, however, let us first turn once more to Bouyer, focussing on the second facet of his thesis which we have omitted in our discussion above.

\section{Louis Bouyer on the Fate of Protestantism in Modernity}

Do the metaphysical underpinnings of the Reformers' thought make any difference at all? Does it matter whether they moved between different metaphysical frameworks (as we have suggested) or expounded their insight in a nominalist framework (as Bouyer contended)? The two most substantial reviews which The Spirit and Forms of Protestantism received after its publication, by the Catholic theologian Robert Roquette and by the Protestant theologian Gabriel Widmer, different though they were in their respective assessments of the book, converged on pondering this question. Roquette wonders whether Protestants would not still think that Luther was Luther, even if his metaphysics turned out to be Thomist. ${ }^{99}$ Widmer confirms this suspicion, boldly claiming that even if the Reformers had been Thomists, nothing would have been different about their teachings. ${ }^{60}$ The question raised by these reviewers is therefore whether the Reformers' metaphysics - whatever it is - makes any difference at all to the way they were perceived by their Protestant heirs.

Bouyer answered this question emphatically in the affirmative, and elaborates on it in his various chapters on the historical development of Protestantism. ${ }^{61} \mathrm{He}$ argues that the legacy of nominalism within Protestantism gradually took over, muting or stifling the genuine discoveries of the Reformation, to the

\footnotetext{
${ }^{59}$ Robert Roquette, “Du protestantisme à l'Église (Book Review),” Études 285, no. 2 (1955): 133.

${ }^{60}$ Widmer, “Du protestantisme à l'Église (Book Review)," 47.

${ }^{61}$ Here and throughout the book, Bouyer uses the term "Protestantism" in a somewhat essentialist way. While he is undoubtedly aware of the variety of its historical instantiations, he nonetheless presupposes that there is a clearly definable essence of what constitutes Protestantism which serves as its unifying principle. In this regard, Bouyer's use and definition of "Protestantism" arguably remains closer to Harnack's than he would have preferred, as Timothy Stanley has suggested. Timothy Stanley, Protestant Metaphysics after Karl Barth and Martin Heidegger (London: SCM Press, 2010), 13 n. 64.
} 
point of inverting them, starting off by observing that the liberal, individualistic Protestants of his day would have been unanimously "branded" by the Reformers as "as infamous heretics." 62

If one is prepared to follow Bouyer in this assessment, then this raises the question why Protestantism has moved so far from its origins in the Reformation. The key reason for this, according to Bouyer, lies precisely in the "unhappy association of the great religious affirmations of the Reformation with the disastrous presumptive principles of nominalism" which we discussed above. ${ }^{63}$ The girdle of nominalism gradually smothered the life of Protestantism's finest principles. According to Bouyer, this stifling happened in two phases; first in the Protestant orthodoxies, and then through theological liberalism. In the various Protestant orthodoxies, the system, by its own weight, oppressed the views it claimed to serve. This subsequently encouraged the emergence of theological liberalism, which wanted to liberate itself from oppressive systems. ${ }^{64}$

Through this double movement, both the systemized solidification of living truths, and the breaking of all bonds provoked by it, many of the fundamental insights of the Reformation were turned on their head over the course of the history of Protestantism, Bouyer holds. An example for this would be the Reformation's emphasis on the authority of Scripture. The nominalist either-or between human and divine agency led in Protestant orthodoxy to a strong emphasis on the Divine inspiration of Scripture at the expense of its human authors. This was carried to extremes with some claiming that even the Masoretic punctuation of the text of the Hebrew Scriptures were divinely inspired. In reaction to this, yet still in keeping with the nominalist either-or, the Divine origin of the Scriptures was thrown overboard after the human element of it came to force itself on the attention of Protestant exegetes. ${ }^{65}$

Another example of a reversal of Reformation insights which Bouyer mentions is the "strong trend ... running through modern Protestantism ... to

\footnotetext{
62 Bouyer, The Spirit and Forms of Protestantism, 22.

${ }^{63}$ Ibid., 199.

${ }^{64}$ Cf. ibid., 200.

${ }^{65}$ Cf. ibid., 208f.
} 
justify God to man on the sole ground of utility."66 This, he contends, undoes everything that Calvin stood for: "Instead of God being the sole end of the world and of man, man becomes the sole reason for God." 67 Yet this development was no coincidence either, Bouyer claims. Calvin's soli Deo gloria was systematized based on a nominalist model of competition, so that God could only be exalted at the price of debasing human beings. It is inevitable that the inverse tendency - to raise the position of human beings - necessarily brings with itself a debasement of God.

Bouyer refuses to view reversals like these as merely accidental, or even 'only' as tragic. On the contrary, he holds that they were necessary. Given that Protestantism was entwined, right from the start, with a nominalist framework predicated on either-or dualisms, it could not escape these detrimental developments. As mentioned above, Bouyer moreover does not believe that such developments can be undone by merely returning to a kind of "original Protestantism." This is because the impetus for later developments is already there at the origin - through the Reformation's unacknowledged and unholy alliance with nominalism. Where Protestantism flourished, Bouyer continues, this was only because it had effectively broken with this alliance. This is what he believes happened in all Protestant revivals: Whenever Protestantism thrived, such as in its various revival movements, then this was because it broke the "shell in which the original Protestantism had imprisoned its most positive principles." 68

In Protestant revivals, Bouyer believes, Protestants liberated themselves from the influence of nominalism, but did so unwittingly. A next step would be to become aware of this detrimental influence. The only viable solution to escape the vicious circle is therefore a "radical criticism of what the first Protestants kept of a decadent medieval system without noticing it." ${ }^{69}$ It is only then that a return to the genuine insights of the Reformation can become fruitful again. Without such an awareness and criticism, a ressourcement from the Reformation

\footnotetext{
66 Ibid., 205.

67 Ibid.

68 Ibid., 214.

69 Ibid., 270.
} 
will always mean to return to a bond between its positive principles and a negative framework that had nothing to do with them. Returning to this bond without being aware of it, however, would only mean to tighten it still further. ${ }^{70}$

Given our modification of Bouyer's systematic thesis above, what can be said about his historical thesis regarding the development and reception of the Reformers' thought beyond the Reformation? If Reformation thought was more fundamentally complex than Bouyer recognised, dwelling simultaneously in two metaphysical frameworks, as we suggested, in what ways does this insight enhance our understanding of its development and reception by later generations of Protestants? It is to these questions that we shall now turn.

\section{On the Development and Retrieval of a Complex Legacy: Struc- tures of Resistance and Memory}

If the Reformers simultaneously inhabited two metaphysical frameworks, rather than being trapped in one supposedly stifling framework, as Bouyer held, then the development of their legacy over the course of the past 500 years can no longer be usefully described as a story of positive truths caught up in a stifling, negative framework. At the very least, the element of fateful necessity which is characteristic for Bouyer's historical thesis cannot be upheld. As seen above, Bouyer argued that it was inevitable that some of the insights of the Reformation were subsequently overturned, precisely because of the nature of the metaphysical framework in which the Reformers, in his estimation, expressed their views. If however, as we have seen, the framework behind the Reformers' thought was not uniform, then there cannot have been such an historical necessity. Rather, the Reformers' legacy could have potentially evolved differently.

Our case study has shown that elements of what Bouyer described as "nominalism" were indeed present in Reformation thought: a univocal structure of being and a concomitant competitive framing of the relationship between Divine and human causality. Our case study has equally shown, however, that

70 Cf. ibid., 232. 
there were other metaphysical forces at work in Reformation thought as well. Peter Martyr Vermigli at least partially inhabited a metaphysics predicated on a qualitative difference between the being of God and of creatures, and on a notion of Divine-human cooperation (and we have seen how secondary scholarship suggests a similar dynamic in Luther and Calvin). Because of these other metaphysical forces, any eventual overturning of Reformation affirmations cannot have been an inexorable fate. Even if it is granted that it was under the influence of univocal ontological structures that some Reformation insights were eventually overturned, this does not sufficiently explain why these structures should have prevailed over the alternative metaphysical structures which had equally been present in the Reformation.

Why, then, did the metaphysically univocal strand of Reformation thought eventually gain the upper hand? One possible reason for this is that it resonated with and was enforced by larger cultural and philosophical developments. For, as others have argued, "nominalist", univocal or competitive structures of being gradually became prevalent in the West in the past few hundred years, manifesting themselves in so-called modern developments such as the secularisation of knowledge, the individualisation and fragmentation of society and the rise of a monetary economy. ${ }^{71}$ At least since Max Weber's famous thesis on the nexus between Protestantism and capitalism, moreover, the question whether and how the Reformation was causally involved in these developments has been hotly debated. ${ }^{72}$ Brad Gregory is a recent commentator who emphatically holds the view that the Reformation is causally linked to key elements of contemporary Western culture. ${ }^{73}$ In particular, he takes the view that the disagreements over what was Christian in the Reformation, kindled and sustained as they were by the sola scriptura principle in its uncoupling from Church tradition, produced a "wide range of incompatible truth claims", which necessarily

\footnotetext{
${ }^{71}$ Eric Alliez, Capital Times: Tales from the Conquest of Time (Minneapolis: University of Minnesota Press, 1996); Gillespie, The Theological Origins of Modernity; Milbank, Beyond Secular Order; Pfau, Minding the Modern: Human Agency, Intellectual Traditions, and Responsible Knowledge.

${ }^{72}$ Max Weber, Die protestantische Ethik und der Geist des Kapitalismus (Tübingen: Mohr, 1934).

${ }^{73}$ Brad S. Gregory, The Unintended Reformation: How a Religious Revolution Secularized Society (Cambridge MA: Belknap Press, 2012).
} 
had to relativize each other. ${ }^{74}$ This is why the Reformation, according to Gregory, is "the most important distant historical source for contemporary Western hyperpluralism with respect to truth claims about meaning, morality, values, priorities and purpose." 75

If the Reformation was not characterized by a univocal metaphysics only, however, it becomes more problematic to hold a line of argument which makes of the Reformation a motor of modernity while predicating modernity on univocal structures of being. To be sure, our thesis about the metaphysical complexity of the Reformation does not make the argument of a certain nexus between the Reformation and certain so-called modern developments impossible, precisely because it grants that there were univocal structures of being present in the Reformation. What it challenges, however, are accounts which claim the Reformation to be linked to these kinds of developments only - and Gregory, even though certainly aware of the intricacy of the genealogical claims he is making, sometimes seems to take this line.

Let us return to the question why the reception history of the Reformers' thought has until relatively recently been dominated by the univocal strand of their thought. As we have suggested, it is likely that the history of the reception of Reformation thought was shaped by broader developments of the history of the West especially insofar as the metaphysical complexity of Reformation thought meant that it was somewhat malleable. Some see this "malleability" as a virtue. In Todd Billings' view, it was a strength of the Reformers' thought that they did not settle for one metaphysical framework. "Bringing closure on points of metaphysical ambiguity", for Billings, would not be desirable. ${ }^{76}$ The fact that Calvin's thought was somewhat vague metaphysically left it "open to be adapted to a wide range of metaphysical frameworks."77 This is an insightful conclusion, regardless of how one evaluates its desirability.

What significance, however, did the adaptability of Reformation theology to a number of metaphysical frameworks have for the development of

\footnotetext{
74 Ibid., 95.

75 Ibid., 369

76 Billings, Calvin, Participation, and the Gift: The Activity of Believers in Union With Christ, 195.

77 Ibid., 194.
} 
Reformation thought? It seems likely that this meant that the heirs of the Reformation were able to embrace whatever framework became culturally prevalent. If univocal structures of being have become prevalent in the last few centuries in the West, as many commentators believe, ${ }^{78}$ then this suggests a reason why the univocal strands in Reformation thought have become dominant. Or, to put this differently, insofar as a certain metaphysical malleability was constitutive of Reformation thought, this meant that it had few structures of resistance in place against the influence of the larger cultural and philosophical developments of the West in the past centuries, as mentioned above (secularisation, individualisation, fragmentation). In short, therefore, the reasons why one metaphysical strand present in Reformation thought came to flourish, whereas another did not, seem to lie not so much in the Reformation itself as in the powerful influence of what came to be known as modernity. ${ }^{79}$

This leads us to one final consideration: If it is true that there was a metaphysical complexity at the heart of the Reformation, why is it that we have become aware of it only recently ${ }^{80}$ The clue to answering this question lies in what we have suggested above about the powerful influence of modernity on the reception of the Reformation: As readers of Reformation thought we ourselves are influenced by the dominance of the univocal framework. (Our access

\footnotetext{
78 See above, footnote 71 .

79 Once more, this indicates that those who wish causally and tightly to link the Reformation to "modern" developments are missing the mark. If one were to charge Reformation thought for being in some ways complicit in these developments, then a more sophisticated line of argument might run as follows: The metaphysical complexity of the Reformation, in its sheer ability of inhabiting multiple metaphysical frameworks at once, could be predicated on a "higher-level" univocal metaphysics. This is because the condition of possibility of a plurality of metaphysical frameworks depends on the possibility of an epistemological distancing between the thinking subject and the world. This kind of distancing, however, is characteristic only for a metaphysical framework in which essence and existence are not inherently linked. Such a "formal distinction" is moreover historically associated with the univocity of being, as Gilson has shown (Étienne Gilson, Jean Duns Scot: Introduction À Ses Positions Fondamentales, Études de Philosophie Médiévale 42 (Paris: J. Vrin, 1952), 243-48.) Is it therefore conceivable that the two metaphysical frameworks we observed in Reformation thought were at a higher level governed by a framework which allowed for this plurality, and which, as such, leaned towards the univocity of being, and hence towards the "modern" developments mentioned?

80 Parts of Henri De Lubac's and Maurice Blondel's works can be seen as foreshadowing this, without however dealing with the Reformation specifically. See for instance Blondel's engagement with extrinsicism in History and Dogma, Maurice Blondel, The Letter on Apologetics \& History and Dogma, trans. Alexander Dru and Illtyd Trethowan (Grand Rapids MI: Eerdmans Publishing, 1964).
} 
to historical texts is always historically mediated. There is a self-reflexivity at play: when thinking about history and reading its sources, we cannot step outside the particular historical moment we inhabit. It is possible, however, to thematise this redoubling of historical perspectives through exposing it, just as according to the artistic or literary figure of the mise-en-abyme.) From the perspective of a time in which "modern", univocal tendencies were most fully developed, the univocal elements in the legacy of the Reformation were understood best. Readers of the Reformers' thought saw in it primarily what resonated with the predominant framework of the culture in which they lived. Put negatively, the more they themselves were "modern", the more it was difficult for them to perceive what was not so "modern" in the work of the Reformers. It would seem that for us, who are now living in (what is commonly agreed to be at least) late modernity, 81 it has become easier to perceive other metaphysical frameworks present in the Reformation.

Moreover, with the critical distance to "high modernity" growing, it is likely that the ways in which the insights of the Reformation have long been construed in ways which were tinted by a culturally dominant univocal framework will continue to emerge more fully. The debates in New Testament scholarship about the "old" and "new" perspectives on Paul are an indication of this. Indeed, proponents of the new perspective have argued that certain "old perspective" readings of "works of the law" (as condemnable because they indicate the futile human attempt to earn salvation) which were traditionally associated with the Reformation and its heirs, are not in line with what Paul understood by the term (which is more to do with community markers of the old covenant). ${ }^{82}$ Insofar as the Reformation prided itself on its faithfulness to the Scriptures, it might emerge that the "old" understanding of Paul is not so much a

\footnotetext{
81 See for instance Charles Taylor, A Secular Age (Cambridge MA: Belknap Press, 2007).

82 The "old" perspective is exemplified in the work of the Lutheran Bultmann, whereas exponents of the "new" perspective are Sanders, Dunn and Wright. See Rudolf Bultmann, Theologie des Neuen Testaments (J.C.B. Mohr, 1953); Ed P. Sanders, Paul (Oxford University Press, 1991); James D. G. Dunn, The New Perspective on Paul (Grand Rapids, MI: Eerdmans, 2008); N. T. Wright, Paul in Fresh Perspective (Minneapolis: Fortress Press, 2005). (I am indebted to Matthew Thomas for these references).
} 
"Protestant" understanding per se, but only a particular modern reading of the Reformation and its profoundly complex legacy. ${ }^{83}$

${ }^{83}$ I would like to thank the following people for feedback on this article and fruitful discussions on issues related to it: Catherine Pickstock, Jon MacKenzie, Ragnar Mogård Bergem, John Bugbee, Stefan Baumann, Nathan Lyons, Barnabas Aspray and the Noesis Seminar of the Cambridge University Faculty of Divinity. 